\title{
HARMONISASI PERDA NOMOR 4 TAHUN 2011 TENTANG RTRW KOTA MALANG DENGAN PERUNDANG-UNDANGAN BIDANG LINGKUNGAN HIDUP
}

\author{
Surya Anoraga \\ Fakultas Hukum Universitas Muhammadiyah Malang \\ Jl. Raya Tlogomas, No. 246 Dau, Malang \\ Email: anoragasurya@ymail.com
}

\begin{abstract}
Law that positively regulates the imposition of civil sanctionx, administrative sanctions and criminal sanctions as regulated in Law Number 26 of 2007 on Spatial Planning and more on the local regulation Malang No. 4 of 2011 on Spatial Planning Malang Year 2010- 2030 $(R T R W)$. Administrative and criminal sanctions as a sanction premium remedium while criminal sanctions as a sanction ultimum remedium. Former Act and regulation are still not meticulous in designing/forming. That is evidenced still weakness in some of the provisions in the legislation are still related to civil sanctions, administrative and ceiminal. The legislator has not been meticulous in making decisions RTRW. Hence it need for harmonization between laws and regulations both at the level of local regulations and at the level of the Act.
\end{abstract}

\section{Keywords: Sanctions, Harmonization, Spatial Planning}

\begin{abstract}
Abstrak
Hukum yang secara positif mengatur pemberian sanksi perdata, sanksi administratif dan sanksi pidana sebagaimana diatur dalam Undang-Undang Nomor 26 Tahun 2007 tentang Penataan Ruang dan lebih pada Peraturan Daerah Malang Nomor 4 Tahun 2011 tentang Penataan Ruang Kota Malang Tahun 2010-2030 (RTRW). Sanksi administratif dan pidana sebagai sanksi premium remedium, sementara sanksi pidana sebagai sanksi ultimum remedium. Undang-undang dan peraturan sebelumnya masih belum teliti dalam mendesain/menyusunnya. Hal ini dibuktikan dengan masih lemahnya beberapa ketentuan dalam peraturan perundang-undangan yang masih berkaitan dengan sanksi perdata, administratif dan pidana. Regulasi pembentuknya belum teliti dalam mengambil keputusan RTRW. Sehingga perlu harmonisasi antar peraturan perundang-undangan baik di tingkat peraturan daerah maupun di tingkat Undang-Undang.
\end{abstract}

\section{Kata kunci: Sanksi, Harmonisasi, Rencana Tata Ruang Tata Wilayah}

\section{A. PENDAHULUAN}

Di Indonesia sejak dekade tahun 200-an sampai dengan tahun 2016 atau tahun-tahun berikutnya, kota-kota besar yang seperti Jakarta, Medan, Bandung, Bogor, Semarang, Surabaya, Menado, Makasar, Balikpapan, Denpasar dan kota-kota lainnya, tidak ketinggalan kota Malang mengalami perkembangan penduduk pertumbuhan rumah/pemukiman, pertumbuhan perdagangan/pertokoan dan mall yang begitu pesat. Beberapa alasan mengapa kota-kota itu tumbuh kembang dengan cepat atau dikenal dengan istilah " interest city: antara 
pertama dikota banyak lapangan pekerjaan dibuka, kedua dikota ada daya tarik bagi penduduk/warga diluar kota berpindah karena banyak kegiatan hiburan (seperti taman rekreasi, makanan kuliner/cafe-cafe bertebaran , permainan/game, beutik modern, dan aksesoris laki-laki dan perem) termasuk banyak fasilitas yang dibangun dikota misalnya pendidikan modern baik berskala nasional, regional bahkan internasional, real estate, apartemen, banyak hotel berkelas dari bintang satu sampai dengan bintang lima dan lain-lain, fasilitas kesehatan yang lengkap seperti rumah sakit berskala tipe A dan rumah sakit internasional.

Namun, kota-kota tersebut diatas dalam perkembangannya tidak berjalan mulus atau tumbuh kembang tidak sesuai dengan kemampuan kota menampung percepatan pertumbuhan fasilitas fisik/bangunan, kendaraan bermotor, migrasi penduduk dan lain-lain. Fenomena ini juga terjadi wilayah kota Malang (Tribina Kota Malangmena). Hal ini ditandai adanya kebijakan pimpinan daerah (Walikota Malang) sejak tahun 1996 sampai dengan 2015 misalnya dengan berdirinya Mall Matos, Mall Dinoyo, Mall Blimbing, pendirian rumah toko yang sebagian besar bertebaran hampir disemua kecamatan, pendirian diskotik, pendirian apatemen Soekarno Hata,pendirian Rumah sakit di Soekarno Hatu, bentuk-bentuk kebijakan semacam itu menimbulkan berbagai reaksi dari masyarakat /warga kota Malang karena menimbulkan problem lingkungan seperti kemacetan dan kepadatan lalu lintas, merusak tatanan lingkungan alam (pohon-pohong ditebang), ketidaknyamanan lingkungan hidup bertetangga (padatnya rumah-rumah dan berhimpitan), ketidaknyamanan jalan raya yang banjir saat musim hujan dan kriminalitas bertambah dan lain-lain dampak lingkungan.

Selain kebijakan pimpinan daerah yang cenderung tidak pro lingkungan yang berkelanjutan namun regulasi daerah (di era otonomi daerah) belum mendukung sepenuhnya menuju pembangunan kota hijau berkelanjutan. Payung hukum telah dimodernisasi dengan keberadaan Undang-Undang Nomor 32 Tahun 2009 tentang Perlindungan dan Pengelolaan Lingkungan Hidup, undang-undang yang lain seperti Undang-undang Nomor 26 Tahun 2007 tentang Penataan Ruang, Undang-Undang Nomor 2 Tahun 2015 tentang Penetapan Peraturan Pemerintah Pengganti Undang-Undang Nomor 2 Tahun 2014 tentang Perubahan Atas Undang-Undang Nomor 23 Tahun 2014 tentang Pemerintahan Daerah Menjadi Undang (sebelum perpu ini masih berlaku Undang-Undang Nomor 32 Tahun 2004 tentang Pemerintahan Daerah), dan ditunjang dengan peraturan pelaksana UU Organik seperti Paraturan Daerah Kota Malang Nomor 4 Tahun 2011 tentang Rencana Tata Ruang Wilayah Kota Malang 2010-2030.

Dan menurut peneliti, ada kecenderungan pembentukan Perda RTRW kota Malang sejak reformasi sampai sekarang tidak sejalan dengan UU organiknya. Dari situlah peneliti tertarik mengkaji dari sisi regulasi/produk hukum yang telah dibuat anatar legialatif dan eksekutif daerah kota Malang dengan judul penelitian : "Harmonisasi Perda Nomor 4 Tahun 2011 Tentang RTRW Kota Malang Dengan Perunndang-undangan di Bidang Lingkungan Hidup Di Indonesia” . Peneliti membatasi yang diperbandingkan dari aspek regulasi sanksi perdata, administratif dan pidana berkenaan tata ruang didaerah Kota Malang dengan perundang-undangan diatasnya. 


\section{B. RUMUSAN PERMASALAHAN}

Dari latar belakang/pendahuluan diatas, penulis mengemukakan masalah yaitu

1. Apakah ada harmonisasi Perda Nomor 4 Tahun 2011 tentang RTRW Kota Malang dengan peraturan perundang-undangan di bidang lingkungan hidup di Indonesia?

2. Bagaimanakah upaya mengharmonisasikan Perda Nomor 4 Tahun 2011 dengan perundang-undangan organik lainnya seperti Undang-Undang Nomor 26 Tahun 2007 Tentang Penataan Ruang, Undang-Undang Nomor 23 Tahun 2014 Tentang Pemerintahan Daerah dan Undang-Undang Nomor 32 Tahun 2009 Tentang Perlindungan dan Pengelolaan Lingkungan Hidup?

\section{METODE PENELITIAN}

Penulis memilih tipe yang selaras dengan rumusan masalah yaitu tipe penelitian normatif atau doctrinal. Selain itu menggunakan beberapa pendekatan antara lain "conceptual dan statute approach". Pendekatan ini dengan melakukan penelusuran berbagai produk hukum dibidang lingkungan hidup di Indonesia antara lain seperti UUD 1945 amandemen ke-IV, UU No.32 Th.2009 tentang Perlindungan dan Pengelolaan Lingkungan Hidup dan lain-lain

Dalam pencaharian dokumen hukum berupa perundang-undangan resmi (termuat dalam lembaran Negara/daerah) sebagai bahan hukum primer (primary sources) dan bahan hukum sekunder ('secondary sources" or "authorities") berupa buku-buku dan Hukum lingkungan , Hukum Pemerintahan Daerah, Hukum Tatat ruang/perkotaan. Sedangkan teknik pengumpulan dokumen dengan cara inventarisasi secara sistematis berdasarkan obyek masalah yang hendak diteliti dan Studi kepustakaan juga ditunjang menggunakan penelusuran website/internet. Bahan hukum baik primer maupun sekunder yang telah diperoleh secara sistematis, selanjutnya diolah dan dikualifikasikan. Dengan mengkaji norma-norma dalam UUD 1945 amandemen ke-IV, UU No.32 Tahun 2009 tentang Perlindungan dan Pengelolaan Lingkungan Hidup, Undang-undang Nomor 26 Tahun 2007 tentang Penataan Ruang, Undang-Undang Nomor 2 Tahun 2015 tentang Penetapan Peraturan Pemerintah Pengganti Undang-Undang Nomor 2 Tahun 2014 tentang Perubahan Atas Undang-Undang Nomor 23 Tahun 2014 tentang Pemerintahan Daerah Menjadi Undang Undang dan ditunjang dengan peraturan pelaksanaan yaitu Paraturan Daerah Kota Malang Nomor 4 Tahun 2011 tentang RTRW Wilayah Kota Malang 2010-2030.

\section{PEMBAHASAN}

Peradaban modern yang dicapai melalui pembagunan industri telah mampu mengantarkan kehidupan manusia pada tingkat kesejahteraan yang luar biasa. Manusia modern telah menjadikan segala persoalan pemecahanya menjadi mudah. Di balik kesuksesan yang dicapai, manusia telah mengabaikan lingkungan, sehingga terjadi degradasi lingkungan yang amat mengkhawatirkan kehidupan manusia sendiri (Absori, 2009). Situasi seperti itu tampak 
tersebar diberbagai lingkungan dikota/metropolis (termasuk kota Malang), dan asumsi atau fenomena perkotaan menjadikan bangunan fisik dinomorsatukan daripada keseimbangan lingkungan alam dan buatan. Hal ini sejalan dengan sinyalemen yang dikemukakan oleh Kevin Lynch dalam tulisan tentang The City as Environment, berceloteh bahwa penampilan dan wajah kota bagaikan mimpi buruk;tunggal rupa, serba sama, tak berwajah, lepas dari alam, dan sering tidak terkendali, tidak manusiawi. Air dan udaranya kotor, jalan-jalan sangat berbahaya dipadati kendaraan, papan reklame mengganggu pandangan, pengeras suara memekakan telinga. Jurang kaya-miskin makin mengangan mencolok mata, komunitas yang guyub pecah menjelma menjadi masyarakat patembayan yang dilandasi kalkulatif (Weber) dan kepekaan moral yang disepakati bersama makin meluntur (Durkheim) dan (Eko Budihardjo,1997). Penataan ruang kota sungguh rumit dan pelik karena tidak mau menyangkut benturan antara pendekatan teknokratik komersial dan humanis (Eko Budiardjo, 1997).

Di Indonesia kerusakan dan pencemaran lingkungan hidup telah terjadi dimana-mana. Dari tahun ke tahun akumulasinya selalu bertambah dan cenderung tidak dapat terkendali, seperti kerusakan dan kebakaran hutan, banjir pada waktu musim penghujan, dan kekeringan pada waktu musim kemarau. Berbagai bencana alam terjadi diberbagai daerah, seperti banjir bandang, tanah longsor...semua itu akibat perilaku manusia yang menempatkan alam sebagai komuditas yang hanyadiperlakukan sebagai obyek eksploitasi, media pembuangan dan kegiatan industri tanpa menghiraukan bahwa lingkungan itu materi yang mempunyai keterbatasan dan bisa mengalami degradasi ( Absori, 2009).

Untuk menjaga keseimbangan alam semesta ciptaan Tuhan YME, agar tidak semakin hancur oleh tingkah laku manusia /masyarakat, prinsip dasar atau asas-asas sebagai pedoman (A.Hamid S. Attamimi,1990) atau "guide" atau arahan dalam menata, merawat, memelihara lingkungan hidup dimanapun khususnya diperkotaan, mutlak diperlukan baik bagi pengambil kebijakan diperkotaan, perencana perkotaan, masyarakat, industriawan, konglomerasi dan sebagainya yang berkepentingan dalam membangun kota yang berkelanjutan demi kesejahteraan manusia yang akan datang. Adapun asas-asas penting antara lain:tanggungjawab negara,kelestarian dan berkelanjutan, keserasian, keseimbangan, manfaat, kehatihatian, keadilan, ditunjang dengan asas-asas tata ruang yang berfungsi sebagai pedoman antara lain: kepastian hukum dan keadilan, keterbukaaan, akuntabilitas, perlindungan kepentingan umum, keterpaduan, keselarasan keserasian, keseimbangan, keberdayagunaan, keberhasilgunaan. Oleh karena itu asas-asas tersebut seharusnya penerapannya dituangkan dalam regulasi lingkungan dan penataan ruang mulai dari payung regulasi sampai dengan peraturan perundangan dibawahnya (Peraturan Pemerintah, Peraturan gubernur, peraturan daerah propinsi, peraturan daerah kota, kabupaten dan lain-lain).

Berkenaan untuk mencegah atau menanggulangi pencemaran atau perusakan lingkungan baik didarat, dilaut maupun didarat, prinsip-prinsip umum kebijaksanaan lingkungan (general principles of policy environmental) mutlak dikemukakan, antara lain Abatemen at the source (penanggulangan thd. Sumbernya); Best practicable means /best tehnical means/ the best available technology (BAT) (sarana praktis yg terbaik /sarana teknis yang terbaik); Polluter pays principle ( prinsip pencemar membayar), Stand still principle (prinsip cekal / 
cegah tangkal), Principle of regional differentiation (prinsip perbedaan regional), dan Het beginsel van de omkering van de bewijslast (beban pembuktian terbalik)( Siti Sundari Rangkuti,1996) . Ke enam prinsip umum ini diberlakukan di negara maju seperti Belanda dan negara maju lainnya, timbul pertanyaan apakah negara Indonesia menganut kebijakan lingkungan seperti itu, tentu bisa dicermati dalam UU payung yaitu UU No.32 tahun 2009.

Berbagai kebijakan lingkungan yang telah dituangkan dalam regulasi lingkungan masih saja ditemui dalam menuangkannya ke norma-norma positif, ada kekurangtepatan atau kekurang cermatan. Untuk menghindari tumpang tindih antar perundang-undangan itu diperlukan syarat-syarat penting yang disebut asas-asas pembentukan perundang-undangan sebagai standar bagi pembuat perundang-undangan yaitu hukum harus dituangkan dalam aturan-aturan yang berlaku umum dan tidak dalam penetapan-penetapan yang berbeda satu sama lainnya; hukum harus diumumkan dan mereka yang berkepentingan dengan aturan aturan hukum harus dapat mengetahui isi aturan-aturan tersebut; aturan-aturan harus diperuntukkan bagi peristiwa-peristiwa yang akan datang dan bukan untuk kejadian-kejadian yang sudah lalu, karena perundangan mengenal yang lalu selain tidak dapat mengatur perilaku, juga dapat merusak kewibawaan hukum yang mengatur masa depan; aturan hukum harus dapat dimengerti, sebab jika tidak demikian orang tidak tahu apa yang harus diperbuatnnya; aturan-aturan hukum tidak boleh saling bertentangan, sebab apabila hal itu terjadi orang tidak tahu lagi akan berpegang pada aturan yang mana; aturan hukum tidak boleh meletakkan beban/persyaratan yang tidak dapat dipenuhi oleh mereka yang bersangkutan ; aturan hukum tidak boleh sering berubah, sebab apabila demikian orang tidak dapat mengikuti aturan mana yang masih berlaku; penguasa/pemerintah sendiri harus juga menaati aturan-aturan hukum yang dibentuknya, sebab apabila tidak demikian hukum tidak dapat dipaksakan berlakunya; sedangkan menurut Bentham, yang dapat mempengaruhi undang-undang (statute law) dan dapat dijadikan asas-asas bagi pembentukan pertundangundangan. Ketidaksempurnaan tersebut dibaginya dalam dua derajat/tingkatan, derajat pertama disebabkan antara lain: arti ganda (ambiguity), kekaburan (obscurity), terlalu luas ( overbulkiness), sedangkan derajat kedua disebabkan hal-hal antara lain: ketidak tepatan ungkapan (unsteadiness in respect of expression), ketidaktepatan tentang pentingnya sesuatu (unsteadiness in respect of import), berlebihan (redundancy), membingungkan (entanglement), tanpa tanda yang memudahkan pemahaman (nakedness in respect of helps to intellection) dan lain-lain (A.Hamid S.Attamimi, 1990).

Justru dalam praktek pembuatan perundang-undangan, mulai dari UUD, UU, PP ....Perda masih ditemuai kelemahan baik derajat pertama maupun derajat kedua sebagaimana dikemukakan oleh Bentham (A.Hamid S. Attamimi,1990). Hal yang penting juga menurut peneliti/penulis berkaitan dengan perundang-undangan yang saling bertentangan/ tidak selaras/tidak sinkron, kajian ini berkenaan dengan ilmu tentang norma-norma hukum negara, Hans Nawiasky, salah satu murid Hans Kelsen, menurutnya norma-norma berada dalam tata susunan dari atas ke bawah sebagai berikut: pertama, norma fundamental negara (staatsfundamentalnorm), kedua aturan dasar negara/aturan pokok negara (staatsgrundgesetz), ketiga Undang-undang (formal) (formell Gesetz), keempat peraturan 
pelaksanaan serta peraturan otonom (verordnung \& autonome satzung)(A.Hamid S.Attamimi).

Kota Malang menjadi minat masyarakat untuk mengeyam pendidikan, secara otomatis akan berpengaruh terhadap hunian/tempat tinggal para pendatang. Tuntutan untuk menyediakan fasilitas papan/rumah/perumahan makin meningkat ,hal ini ditandai banyak pendirian perumahan, rumah susun, apartemen, dan munculnya mall.plaza, rumah toko (ruko), diskotik, karaoke dan lain-lain tempat aksesoris sebagai ciri kota metropolis. Pengaruh lainnya yang siknifikan adalah banyaknya kendaraan roda dua dan empat sehingga jalan-jalan tidak mampu lagi menampung jumlah kendaraan yang tidak sepadan dengan lebar jalan/ ruas jalan. Akibanya terjadi kemacetan menjadi pemandangan yang biasa sehari-hari di sepanjang jalan di wilayah kota Malang, banjir dimusim hujan dijalan raya terutama di dekat ruko-ruko yang berdiri dan mall, ada rumah-rumah pemukiman yang berdiri di hamparan pinggir sungai dan pertumbuhan rumah disepanjang sungai, papan reklame yang terpasang dikiri, kanan, atas jalan seolah-olah tampak menghalangi pemandangan alam sesungguhnya kota Malang .

Situasi ini sesungguhnya ada tata ruang kota Malang yang ditempati oleh aktifitas yang tidak sejalan dengan keperuntukkannya sebagaimana diatur dalam perda tata ruang/RTRW Kota Malang ( No.4 Th.2007 tentang RTRW Kota Malang Tahun 2010-2030). Dalam kondisi yang demikian peran sanksi hukum mutlak diperlukan, karena sanksi hukum memilki maksud yang baik yaitu agar masyarakat takut melanggar aturan tata ruang yang telah dibuat/diatur oleh pemerintah, selain itu fungsi sanksi hukum untuk mencegah masyarakat (dampak negatif) untuk melanggar dan mengendalikan/memulihkan adanya perbuatan yang dilarang (menyimpangi penggunaan/pemanfaatan ruang yang akan menimbulkan kerusakan/korban) yang pada akhirnya akan mengganggu kenyamanan, kesejahteraan dan ketenangan warga masyarakat yang tinggal/berdomisili kota Malang maupun pendatang dari berbagai daerah termasuk turis yang berkunjung di wilayah Malang. Sengaja oleh Pemerintah Daerah bahwa wilayah kota Malang yang ada ditata penggunaan daratan tentang keperuntukkannya dengan "perencanaan tata kota/penataan kota", dan bahwa penataan wilayah/ ruang memiliki tujuan, sebagaimana diatur dalam UU No.26 Th.2007 pasal 3 yang menyebutkan "penataan ruang bertujuan untuk mewujudkan ruang wilayah nasional yang aman, nyaman, produktif, dan berkelanjutan berlandaskan Wawasan Nusantara dan Ketahanan Nasional dengan:

1. terwujudnya keharmonisan antara lingkungan alam dan lingkungan buatan;

2. terwujudnya keterpaduan dalam penggunaan sumber daya alam dan sumber daya buatan dengan memperhatikan sumber daya manusia; dan

3. terwujudnya pelindungan fungsi ruang dan pencegahan dampak negatif terhadap lingkungan akibat pemanfaatan ruang.

Dari ketentuan ini bahwa tujuan suatu ruang/wilayah ditata/dirancang agar tetap harmonis lingkungan dengan lingkungan lainnya dan sebaliknya menghindari disharmoni, ada keterpaduan pemanfaatan SDA dan SD Buatan, melindungi kemanfaatan ruang/wilayah bukan sebaliknya merusak atau membiarkan terjadi kerusakan ruang dan menghindari 
timbulnya dampat negatif akibat pemanfaatan ruang dan sebaliknya tidak mendukung timbulnya dampak negatif yang lebih atau berlebihan .

Bagaimanakah pengaturan sanksi perdata, sanksi administratif dan sanksi pidana terhadap pelanggaran Hak, kewajiban, partisipasi masyarakat dalam pemanfaatan ruang itu? sebelum menguraikan regulasi sanksi tersebut perlu diketahui mengenai hak asasi, kewajiban warga masyarakat , partisipasi masyarakat terhadap pemanfaatan ruang daratan/lautan/udara. UU No.26 Th.2007 tentang Penataan Ruang telah mengatur seputar hakhak asasi, kewajiban dan partisipasi dalam beberapa: artikel/Pasal 60 yang menyebutkan..."penataan ruang setiap orang berhak untuk: a. mengetahui rencana tata ruang; b. menikmati pertambahan nilai ruang sebagai akibat penataan ruang; c. memperoleh penggantian yang layak atas kerugian yang timbul akibat pelaksanaan kegiatan pembangunan yang sesuai dengan rencana tata ruang;d. mengajukan keberatan kepada pejabat berwenang terhadap pembangunan yang tidak sesuai dengan rencana tata ruang di wilayahnya; e. mengajukan tuntutan pembatalan izin dan penghentian pembangunan yang tidak sesuai dengan rencana tata ruang kepada pejabat berwenang; dan f. mengajukan gugatan ganti kerugian kepada pemerintah dan/atau pemegang izin apabila kegiatan pembangunan yang tidak sesuai dengan rencana tata ruang menimbulkan kerugian"...artikel/ Pasal 61 menyebutkan bahwa ...'Dalam pemanfaatan ruang, setiap orang wajib:a. menaati rencana tata ruang yang telah ditetapkan; b. memanfaatkan ruang sesuai dengan izin pemanfaatan ruang dari pejabat yang berwenang; c. mematuhi ketentuan yang ditetapkan dalam persyaratan izin pemanfaatan ruang; dan d. memberikan akses terhadap kawasan yang oleh ketentuan peraturan perundang-undangan dinyatakan sebagai milik umum...artikel/ Pasal 65 menyebutkan..."(1) Penyelenggaraan penataan ruang dilakukan oleh pemerintah dengan melibatkan peran masyarakat.

(2) Peran masyarakat dalam penataan ruang sebagaimana dimaksud pada ayat (1) dilakukan, antara lain, melalui:a. partisipasi dalam penyusunan rencana tataruang; b. partisipasi dalam pemanfaatan ruang; dan c. partisipasi dalam pengendalian pemanfaatan ruang"...(garis bawah penulis)

Kalau diperhatikan ketentuan diatas, bahwa masyarakat memiliki hak untuk mengetahui akan ruang (daratan,lautan dan udara); kewajiban terhadap ruang serta dapat berperan serta terhadap ruang/wilayah.

Bagaimanakah pengaturan hak, kewajiban dan peran masyarakat di daerah /wilayah Kota Malang, sebaimana perintah UU organik bahwa disetiap propinsi, kota dan kabupaten perlu mengatur rencana tata ruang, sehingga atas perintah UU maka di kota Malang regulasi rencana tata ruang terdapat dalam Perda Kota Malang No.4 Th 2011, beberapa pasal mengatur hal hal sebagai berikut, dalam beberapa artikel 84 menyebutkan...'Dalam penataan ruang, setiap orang berhak : a. mengetahui rencana tata ruang; b. menikmati pertambahan nilai ruang sebagai akibat penataan ruang; c. memperoleh penggantian yang layak dan senyatanya atas kerugian yang timbul akibat pelaksanaan kegiatan pembangunan yang sesuai dengan rencana tata ruang; d. mengajukan keberatan kepada Pejabat berwenang terhadap pembangunan yang tidak sesuai dengan rencana tata ruang di wilayahnya; 
e. mengajukan tuntutan pembatalan izin dan penghentian pembangunan yang tidak sesuai dengan rencana tata ruang kepada Pejabat berwenang; dan f. mengajukan gugatan ganti kerugian kepada pemerintah dan/atau pemegang izin apabila kegiatan pembangunan yang tidak sesuai dengan rencana tata ruang menimbulkan kerugian"...artikel /pasal 85 menyebutkan...”Dalam penataan ruang, setiap orang wajib : a. memelihara kualitas ruang, memelihara ketentuan penggunaan dan ketentuan teknis yang berlaku pada bangunan/lahan yang dikuasainya; b. menaati rencana tata ruang yang telah ditetapkan, berlaku tertib dalam keikutsertaannya dalam penyusunan, pemanfaatan, dan pengendalian penataan ruang; c. memanfaatkan ruang sesuai dengan izin pemanfaatan ruang dari Pejabat yang berwenang;

d. mematuhi ketentuan yang ditetapkan dalam persyaratan izin pemanfaatan ruang; e. memberikan akses terhadap kawasan yang oleh ketentuan peraturan perundangundangan dinyatakan sebagai milik umum..."(garis bawah penulis).

Kalau dicermati hampir regulasi hak asasi dan kewajiban seseorang terhadap ruang yang diatur dalam pasal 60 dan 61 UU No.26 Th.2007 berkenaan hak -hak masyarakat/seseorang seperti mengetahui rencana tata ruang; menikmati pertambahan nilai ruang sebagai akibat penataan ruang; memperoleh penggantian yang layak atas kerugian yang timbul akibat pelaksanaan kegiatan pembangunan yang sesuai dengan rencana tata ruang; mengajukan keberatan kepada pejabat berwenang terhadap pembangunan yang tidak sesuai dengan rencana tata ruang di wilayahnya; mengajukan tuntutan pembatalan izin dan penghentian pembangunan yang tidak sesuai dengan rencana tata ruang kepada pejabat berwenang; dan mengajukan gugatan ganti kerugian kepada pemerintah dan/atau pemegang izin apabila kegiatan pembangunan yang tidak sesuai dengan rencana tata ruang menimbulkan kerugian. Hak-hak ini kesemaunya , ditransfer/diakomodasi oleh pembentuk perda kedalam Perda Kota Malang No.4 Th.20011 yang dituangkan ke dalam pasal 84 dan pasal 85, namun ada 1 (satu) penambahan ayat dalam perda yang tidak diatur oleh UU organik tersebut berkaitan kewajiban seseorang yaitu "memelihara kualitas ruang, memelihara ketentuan penggunaan dan ketentuan teknis yang berlaku pada bangunan/lahan yang dikuasainya". Ini berarti pembentuk perda kota Malang saat itu ,dalam hal ini walikota bersama -sama DPRD menambahkan satu point hak- asasi tersebut. Tambahan hak asasi ini sangat penting karena tidak saja seseorang hanya memanfaatkan ruang saja yang lebih urgen adalah setelah memanfaatkan ruang adalah memelihara ruang tersebut dari sisi kualitas ruang agar tidak menurun/rusak. Timbul pertanyaan bolehkah muata Perda mengatur tambahan hak asasi bagi seseorang/warga masyarakat, menurut penulis kuranglah tepat penempatannya. Seharusnya pengaturan hak asasi manusia lebih tepat diatur dalam perundang-undangan yang lebih atasnya yaitu UU bukan perda yang ini selaras dengan teori berjenjang perundang-undangan dari Nawiasky.

Beberapa ketentuan lainnya, menyebutkan dalam Pasal 86 ...”(1) Partisipasi masyarakat dalam penataan ruang dapat dilakukan, antara lain melalui : a. partisipasi dalam penyusunan rencana tata ruang; b. partisipasi dalam pemanfaatan ruang; dan/atau c. partisipasi dalam pengendalian pemanfaatan ruang. (2) Pelaksanaan peran serta masyarakat dalam proses perencanaan tata ruang wilayah Kota dapat berbentuk : a. pemberian masukan dalam penentuan arah pengembangan wilayah yang akan dicapai; b. pengidentifikasian berbagai potensi dan masalah pembangunan, termasuk bantuan untuk memperjelas hak atas ruang di 
wilayah dan perencanaan tata ruang kawasan; c. pemberian masukan dalam merumuskan perencanaan tata ruang wilayah; d. pemberian informasi, saran, pertimbangan atau pendapat dalam penyusunan strategi pelaksana pemanfaatan ruang wilayah; dan/atau e. pengajuan tanggapan terhadap rancangan rencana tata ruang dan wilayah. (3) Ketentuan lebih lanjut tentang Tata Cara Partisipasi Masyarakat dalam Penataan Ruang akan diatur lebih lanjut dengan Peraturan Kepala Daerah yang selambatlambatnya ditetapkan 24 (dua puluh empat) bulan...".

Ketentuan partisipasi masyarakat dalam penataan ruang sebagaimana telah diatur dalam pasal 65 UU No.26 Th.2007 terutama ayat 2 telah diakomadasi /ditransfer oleh pembentuk Perda kota Malang kesemuannya kedalam partisipasi masyarakat dalam keterlibatan menata ruang /wilayah perkotaan di Malang yang dicantumkan kedalam 86 Perda No.4 Th.2011.

Bagaimanakan regulasi sanksi terhadap pelanggaran pemanfaatan/penataan ruang/wilayah? berkaitan hal ini diatur dalam UU organik (UU No.26 Th.2007) dibedakan dalam beberapa sanksi, yaitu sanksi perdata, administratif dan pidana. Penulis akan menjabarkan satu persatu mengenai sanksi: Pertama, sanksi perdata. Beberapa ketentuan mengenai sanksi perdata sebagaimana disebutkan dalam Pasal 67 ...’(1) Penyelesaian sengketa penataan ruang pada tahap pertama diupayakan berdasarkan prinsip musyawarah untuk mufakat. (2) Dalam hal penyelesaian sengketa sebagaimana dimaksud pada ayat (1) tidak diperoleh kesepakatan, para pihak dapat menempuh upaya penyelesaian sengketa melalui pengadilan atau di luar pengadilan sesuai dengan ketentuan peraturan perundangundangan..."....pasal 75 menyebutkan...”(1) Setiap orang yang menderita kerugian akibat tindak pidana sebagaimana dimaksud dalam Pasal 69, Pasal 70, Pasal 71, dan Pasal 72, dapat menuntut ganti kerugian secara perdata kepada pelaku tindakpidana. (2) Tuntutan ganti kerugian secara perdata sebagaimana dimaksud pada ayat (1) dilaksanakan sesuai dengan hukum acara pidana..".(garis bawah penulis)

Ketentuan diatas dapat penulis jelaskan bahwa manakala ada sengketa mengenai penataan ruang antar pihak dapat diselesaikan secara musyawarah, namun manakala tidak bisa ditempuh jalan kesepakatan, maka bisa diselesaikan melalui jalur peradilan atau diluar peradilah/musyawarah. (Pasal 67). Sedangkan manakala ada perbuatan tindak pidana yang menimbulkan kerugian bagi korban dan diancam sanksi pidana secara bersamaan korban dapat menuntut ganti kerugian secara keperdataan (pasal 75).

Perbuatan tindak pidana apa saja yang bisa menimbulkan kerugian, diatur dalam pasal 69 yang menyebutkan ..." (1) Setiap orang yang tidak menaati rencana tata ruangyang telah ditetapkan sebagaimana dimaksud dalam Pasal 61 huruf a yang mengakibatkan perubahan fungsi ruang, dipidana dengan pidana penjara paling lama 3 (tiga) tahun dan denda paling banyak Rp500.000.000,00 (lima ratus juta rupiah), (2) Jika tindak pidana sebagaimana dimaksud pada ayat (1) mengakibatkan kerugian terhadap harta benda atau kerusakan barang, pelaku dipidana dengan pidana penjara paling lama 8 (delapan)tahun dan denda paling banyak Rp1.500.000.000,00 (satu miliar lima ratus juta rupiah), (3) Jika tindak pidana sebagaimana dimaksud pada ayat (1) mengakibatkan kematian orang, pelaku dipidana dengan pidana penjara paling lama 15 (lima belas) tahun dan denda paling banyak Rp5.000.000.000,00 (lima miliar rupiah)...pasal 70 menyebutkan...'(1) Setiap orang yang memanfaatkan ruang tidak sesuai dengan izin pemanfaatan ruang dari pejabat yang berwenang sebagaimana dimaksud 
dalam Pasal 61 huruf $b$, dipidana dengan pidana penjara paling lama 3 (tiga) tahun dan denda paling banyak Rp500.000.000,00 (lima ratus juta rupiah), (2) Jika tindak pidana sebagaimana dimaksud pada ayat (1) mengakibatkan perubahan fungsi ruang, pelaku dipidana dengan pidana penjara paling lama 5 (lima) tahun dan denda paling banyak Rp1.000.000.000,00 (satu miliar rupiah), (3) Jika tindak pidana sebagaimana dimaksud pada ayat (1) mengakibatkan kerugian terhadap harta benda atau kerusakan barang, pelaku dipidana dengan pidana penjara paling lama 5 (lima) tahun dan denda paling banyak Rp1.500.000.000,00 (satu miliar lima ratus juta rupiah), (4) Jika tindak pidana sebagaimana dimaksud pada ayat (1) mengakibatkan kematian orang, pelaku dipidana dengan pidana penjara paling lama 15 (lima belas) tahun dan denda paling banyak Rp5.000.000.000,00 (lima miliar rupiah)...pasal pasal 71 menyebutkan..."Setiap orang yang tidak mematuhi ketentuan yang ditetapkan dalam persyaratan izin pemanfaatan ruang sebagaimana dimaksud dalam Pasal 61 huruf c, dipidana dengan pidana penjara paling lama 3 (tiga) tahun dan denda paling banyak Rp500.000.000,00 (lima ratus juta rupiah)"..Pasal 72 menyebutkan ...”Setiap orang yang tidak memberikan akses terhadap kawasan yang oleh peraturan perundang-undangan dinyatakan sebagai milik umum sebagaimana dimaksud dalam Pasal 61 huruf d, dipidana dengan pidana penjara paling lama 1 (satu) tahun dan denda paling banyak Rp100.000.000,00 (seratus juta rupiah)...”.(garis bawah penulis)

Kalau dicermati ketentuan pasal 69 ssmapai dengan pasal 72 diatas , perbuatan pidana apa yang disertai kerugian bagi korban dan dapat menuntut ganti kerugian? disebutkan antara lain: orang yang tidak menaati rencana tata ruangyang telah ditetapkan, yang mengakibatkan perubahan fungsi ruang, yang mengakibatkan kerugian terhadap harta benda atau kerusakan barang, yang mengakibatkan kematian orang; orang yang memanfaatkan ruang tidak sesuai dengan izin pemanfaatan ruang dari pejabat yang berwenang, yang mengakibatkan perubahan fungsi ruang, yang mengakibatkan kerugian terhadap harta benda atau kerusakan barang, yang mengakibatkan kematian orang; orang yang tidak mematuhi ketentuan yang ditetapkan dalam persyaratan izin pemanfaatan ruang ;orang yang tidak memberikan akses terhadap kawasan yang oleh peraturan perundang-undangan dinyatakan sebagai milik umum...", Ketentuan ini menimbulkan persoalan apakah dimaksudkan oleh ketentuan ini disamping diberikan sanksi pidana dan denda juga dikenakan secara bersamaan ganti kerugian? Berapa nilai besaran ganti kerugiannya? Jawabannya bisa timbul berdasarkan penafsiran (gramatikal/tata bahasa) dalam penerapan sanksi, penafsiran pertama yang dimaksudkan ganti kerugian adalah pidana denda itu sendiri dan penafsiran kedua adalah selain pidana penjara, dikenakan denda dan ganti kerugian. Seharusnya pembentuk UU memberikan penjelasan mengenai hal ini termasuk besaran nilai ganti kerugian minimal atau maksimal. Bagaimanakah perda kota Malang mengatur sanksi perdata semacam ini? Berdasarkan penelusuran penulis dalam ketetntuan Perda Kota Malang tidak ada satu pasal pun yang secara tegas/spesifik mengatur tuntutan ganti rugi keperdataan/ganti kerugian terhadap korban sebagaimana diatur dalam UU No.26 Th.2007 (mengenai Penataan Ruang), yang disebutkan secara tegas/lugas dalam ketetuan perda hanyalah sanksi administratif dan pidana, sebagaimana disebutkan: Pasal 83 ...” (1) Arahan pengenaan sanksi terhadap pelanggaran terhadap pemanfaatan ruang akan dilakukan dengan pemberian sanksi administratif dan ketentuan pidana ,(2) Pelanggaran terhadap pemanfaatan ruang sebagaimana 
dimaksud pada ayat (1), akan dikenakan sanksi administratif. (3) Sanksi administratif akan diatur ... dengan Peraturan Kepala Daerah yang ditetapkan selambat-lambatnya 24 (dua puluh) bulan setelah diundangkannya Peraturan Daerah ini...”.(garis bawah penulis)

Sedangkan yang dimaksudkan pelanggaran terhadap pemanfaatan ruang adalah izin yang dipersyaratkan dalam kegiatan pemanfaatan ruang sesuai dengan ketentuan peraturan perundang-undangan, seperti : Izin Prinsip, Izin Lokasi, Izin Penggunaan Pemanfaatan Tanah, Izin Mendirikan Bangunan, dll.(penjelasan pasal 72 ayat 2). Seharusnya Perda juga mencantumkan /menambahkan jenis sanksi perdata dengan tegas sebagaimana diatur dalam UU organiknya (pasal 75).

Yang Kedua, berkenaan Sanksi Administratif (sanksi premium remedium)/sanksi permulaan/awal), dalam UU organiknya beberapa pasal mengatur sanksi ini yaitu: Pasal 62 yang menyebutkan ...'Setiap orang yang melanggar ketentuan sebagaimana dimaksud dalam Pasal 61, dikenai sanksi administratif...yang disebutkan dalam Pasal 63...'Sanksi administratif ... dalam Pasal 62 dapat berupa: a. peringatan tertulis; b. penghentian sementara kegiatan; c. penghentian sementara pelayanan umum; d. penutupan lokasi; e. pencabutan izin; f. pembatalan izin; g. pembongkaran bangunan; h. pemulihan fungsi ruang; dan/atau i. denda administratif...”

Ketentuan diatas akan dikenakan sanksi adminstratif manakala seseorang tidak melakukan kewajiban sebagaimana diatur dalam pasal 61...” Dalam pemanfaatan ruang setiap orang wajib: a. menaati rencana tata ruang yang telah ditetapkan; b. memanfaatkan ruang sesuai dengan izin pemanfaatan ruang dari pejabat yang berwenang; c. mematuhi ketentuan yang ditetapkan dalam persyaratan izin pemanfaatan ruang; dan d. memberikan akses terhadap kawasan yang oleh ketentuan peraturan perundang-undangan dinyatakan sebagai milik umum. ..".Lebih tepatnya pemberian macam sanksi administratif dalam ketentuan UU berupa: peringatan tertulis,penghentian sementara kegiatan, penghentian sementara pelayanan umum, penutupan lokasi, pencabutan izin, pembatalan izin, pembongkaran bangunan, pemulihan fungsi ruang; dan/atau denda administratif kepada seseorang karena melakukan pelanggaran izin pamanfaatan ruang. Sedangkan dalam UU No.32 Tahun 2009 tentang perlindungan dan pengelolaan Lingkungan hidup juga mengatur sanksi administratif sebagaimana disebutkan dalam Pasal 76 menyebutkan ...”(1) Menteri, gubernur, atau bupati/walikota menerapkan sanksi administratif kepada penanggung jawab usaha dan/atau kegiatan jika dalam pengawasan ditemukan pelanggaran terhadap izin lingkungan. (2) Sanksi administratif terdiri atas: a. teguran tertulis; b. paksaan pemerintah; c. pembekuan izin lingkungan; atau d. pencabutan izin lingkungan"...Pasal pasal 77 menyebutkan..."Menteri dapat menerapkan sanksi administratif terhadap penanggung jawab usaha dan/atau kegiatan jika Pemerintah menganggap pemerintah daerah secara sengaja tidak menerapkan sanksi administratif terhadap pelanggaran yang serius di bidang perlindungan dan pengelolaan lingkungan hidup" ...pasal Pasal 78 menyebutkan..."Sanksi administratif sebagaimana dimaksud dalam tidak membebaskan Pasal 76 penanggung jawab usaha dan/atau kegiatan dari tanggung jawab pemulihan dan pidana"...pasal Pasal 79 menyebutkan ..."Pengenaan sanksi administratif berupa pembekuan atau pencabutan izin lingkungan sebagaimana dimaksud dalam Pasal 76 ayat (2) huruf $\mathrm{c}$ dan huruf $\mathrm{d}$ dilakukan apabila penanggung jawab usaha dan/atau kegiatan tidak melaksanakan paksaan pemerintah"... pasal 80 menyebutkan..."(1) Paksaan pemerintah sebagaimana dimaksud dalam Pasal 76 ayat (2) huruf b berupa: a. penghentian sementara kegiatan 
produksi; b. pemindahan sarana produksi;c. penutupan saluran pembuangan air limbah atau emisi; d. pembongkaran; e. penyitaan terhadap barang atau alat yang berpotensi menimbulkan pelanggaran; f. penghentian sementara seluruh kegiatan; atau g. tindakan lain yang bertujuan untuk menghentikan pelanggaran dan tindakan memulihkan fungsi lingkungan hidup.

(2) Pengenaan paksaan pemerintah dapat dijatuhkan tanpa didahului teguran apabila pelanggaran yang dilakukan menimbulkan: a. ancaman yang sangat serius bagi manusia dan lingkungan hidup; b. dampak yang lebih besar bagi lingkungan hidup jika tidak segera dihentikan pencemaran dan/atau perusakannya"...pasal 81 menyebutkan...”Setiap penanggung jawab usaha dan/atau kegiatan yang tidak melaksanakan paksaan pemerintah dapat dikenai denda atas setiap keterlambatan pelaksanaan sanksi paksaan pemerintah...".

Memperhatikan sanksi administratif dalam payung hukum dibidang Lingkungan hidup yaitu pasal 78 sampai dengan 81 UU No.32 Th.2009 di atas, sanksi administratif berupa sanksi teguran tertulis, paksaan pemerintah, pembekuan, pencabutan izin. Sanksi Paksaan pemerintah berupa:a penghentian sementara kegiatan produksi; b. pemindahan sarana produksi;c. penutupan saluran pembuangan air limbah atau emisi; d. pembongkaran; e. penyitaan terhadap barang atau alat yang berpotensi menimbulkan pelanggaran; f. penghentian sementara seluruh kegiatan; atau g. tindakan lain yang bertujuan untuk menghentikan pelanggaran dan tindakan memulihkan fungsi lingkungan hidup. Kalau diperbandingkan dengan sanksi administratif dalam UU No.26 Th.2007, sanksi dalam UU No.32 Th.2009 lebih luas dan lengkap karena mencantumkan sanksi paksaan pemerintah berupa ; pemindahan, penyitaan, tanpa teguran manakala pelanggaran yang amat serius dan berbahaya serta pemberian denda atas keterlambatan menjalankan paksaan pemerintah (dwangsom). Muatan ini tidak dicantumkan dalam sanksi administratif dalam UU No.26 Th.2007 .

Dan bagaimana pengaturan sanksi administratif ini dalam Perda Kota Malang? beberapa ketentuan dalam Perda Kota Malang (Perda No.4 Th.2011) Pasal 83 menyebutkan..."(1) Arahan pengenaan sanksi terhadap pelanggaran terhadap pemanfaatan ruang akan dilakukan dengan pemberian sanksi administratif dan ketentuan pidana (2) Pelanggaran terhadap pemanfaatan ruang sebagaimana dimaksud pada ayat (1), akan dikenakan sanksi administratif. (3) Sanksi administratif akan diatur lebih lanjut dengan Peraturan Kepala Daerah yang ditetapkan selambat-lambatnya 24 (dua puluh) bulan setelah diundangkannya...”.

Kalau di perhatikan secara cermat Perda tersebut telah mengakomodasi sanksi administratif sebagaimana diatur dalam UU organiknya, namun isi sanksi dalam perda tidak dengan lugas menyebutkan macam sanksinya yang telah disebutkan dalam UU diatas (Pasal 63), justru pembentuk perda memerintahkan kepada kepala daerah untuk mengeluarkan peraturan kepala daerah yang mengatur macam /jenis sanksi administratif. Menurut hemat penulis, tidak perlu jenis/macam sanksi administratif ini diatur dalam peraturan kepala daerah, lebih tepat disebutkan langsung saja dalam Perda Rencana Tata ruang wilayah Kota Malang No. 4 Th.2011 . Ini berarti pembentuk perda kurang cermat dan kurang logis tidak mencantumkan ketentuan macam/jenis sanksi administratif tersebut atau tidak menjalankan asas kekurang hati hatian dalam pembentukan peraturan (perda0.

Yang ketiga, berkenaan sanksi pidana. Berbicara sanksi pidana ini yang dikatagorikan sebagai "ultimum remedium " (sanksi paling terakhir diterapkan manakala sanksi perdata dan administratif belum mampu membuat jera pelaku melakukan pelanggaran pemanfaatan/ penataan ruang/wilayah ), hal ini diatur dalam beberapa pasal dalam UU No.26 th.2007 yaitu 
pasal 69 sampai pasal 74, namun untuk pasal 69,70,71, dan 72 telah penulis sebutkan diatas, sedangkan pasal sisanya , disebutkan dalam pasal 73..."(1) Setiap pejabat pemerintah yang berwenang yang menerbitkan izin tidak sesuai dengan rencana tata ruang sebagaimana dimaksud dalam Pasal 37 ayat (7), dipidana dengan pidana penjara paling lama 5(lima) tahun dan denda paling banyak Rp500.000.000,00 (lima ratus juta rupiah). (2) Selain sanksi pidana sebagaimana dimaksud pada ayat (1) pelaku dapat dikenai pidana tambahan berupa pemberhentian secara tidak dengan hormat dari jabatannya"...dalam Pasal 74 menyebutkan..."(1) Dalam hal tindak pidana sebagaimana dimaksud dalam Pasal 69, Pasal 70, Pasal 71, dan Pasal 72 dilakukan oleh suatu korporasi, selain pidana penjara dan denda terhadap pengurusnya, pidana yang dapat dijatuhkan terhadap korporasi berupa pidana denda dengan pemberatan 3 (tiga) kali dari pidana denda sebagaimana dimaksud dalam Pasal

69, Pasal 70, Pasal 71, dan Pasal 72. (2) Selain pidana denda sebagaimana dimaksud pada ayat (1), korporasi dapat dijatuhi pidana tambahan berupa: a. pencabutan izin usaha; dan/atau b. pencabutan status badan hukum...”.

Ketentuan sanksi pidana yang telah disebutkan diatas, dapat ditarik kesimpulan bahwa macam/jenis pidananya adalah pidana penjara maksimal,pidana denda maksimal, pidana denda dengan pemberatan, pidana tambahan pemberhentian dengan hormat dan pidana tambahan berupa pencabutan izin usaha dan pencabutan status badan hukum, ketentuan ini dikenakan terhadap korporasi. Ini berarti ketentuan sanksi pidana dalam UU tersebut menggabungkan dengan sanksi administratif (Pasal 73 ayat 2 dan Pasal 74 ayat 2). Dan bagaimanakah pengaturan sanksi pidana dalam perda No.4 Th.2011?

Setelah penulis mencermati ketentuan dalam perda, dalam pasal 96 menyebutkan : ...'Ketentuan pidana terhadap pelanggaran rencana tata ruang dalam Peraturan Daerah ini dikenakan sanksi sesuai dengan ketentuan peraturan perundang-undangan...".

Ketentuan sanksi pidana pasal 96 diatas tidak menjelaskan dengan detail jenis sanksi pidanaya , justru memerintahkan untuk merujuk kedalam pasal-pasal pidana/sanksi pidana perundang-undangan yang berlaku . Ini berarti perundang undangan dimaksud tidak lain adalah UU No.26 Th.2007, sehingga dapat ditarik kesimpulan bahwa perda tersebut mengatur sanksi pidana dengan merujuk pasal 69 sampai dengan pasal 74 UU tersebut. Mengapa perda tidak memuat sanksi pidana pasal 69 sampai dengan pasal 74 UU organik?jawaban ini bisa ditemukan dalam UU No.23 th.2014 tentang Pemerintahan Daerah bahwa perda tidak boleh memuat sanksi pidana yang ancamannya lebih dari 1 th. dan UU No.12 Th.2011.

Itulah ulasan perbandingan pengaturan sanksi perdata, administratif dan pidana dalam UU organik dengan Perda Kota Malang, kalau dianalisis perda tersebut memiliki kelemahan dari sudut pengaturan sanksi keperdataan yaitu perda tidak mencantumkan jenis sanksi perdata termasuk sanksi administratif (dengan detail), ini berarti pembentuk perda belum cermat dan teliti dalam pembuatan/penyusunan perda RTRW tersebut dan tidak sesuai dengan asas-asas pembentukan perundang-undangan (asas kehati hatian). Sedangkan dalam UU No.26 th.2007, pembentuk UU juga belum cermat dan lugas menjelaskan dalam pasal-pasal berkenaan penggabungan sanksi pidana, denda dengan ganti kerugian (serta besaran nilai ganti kerugian) akibat dari perbuatan yang dilarang dalam pemanfaatan/penataan ruang. Ini dapat dikatakan bahwa penyusunan UU bertentangan dengan asas pembentukan perundangundangan yaitu ketidaktepatan tentang pentingnya sesuatu (unsteadiness in respect of import) . 


\section{E. PENUTUP \\ 1. Kesimpulan}

Dalam pemanfaatan/penataan ruang/wilayah di Kota Malang khususnya, hukum positif mengatur juga pengenaan sanksi perdata, sanksi administratif dan sanksi pidana sebagaimana di atur dalam Undang -Undang Nomor 26 Tahun 2007 tentang Penataan Ruang dan lebih lanjut diatur dalam Peraturan Daerah Kota Malang Nomor 4 tahun 2011 tentang Rencana Tata Ruang Wilayah Kota Malang Tahun 2010-2030 (RTRW) . Sanksi Administratif dan perdata sebagai sanksi "premium remedium "sedangkan sanksi pidana sebagai sebagai sanksi "ultimum remedium". Pembentuk UU dan Perda masih belum cermat dan teliti dalam merancang/menyusunnya.

\section{Saran}

Seharusnya pembentuk UU dan perda Kota Malang memperhatikan prinsip-prinsip materiil dan formil dalam pembentuan/penyusunan UU dan Perda terutama dari sisi muatan sanksi perdata dan sanksi administratif dan kedepan sebaiknya dilakukan amademen beberapa pasal dalam UU No. 26 Th.2007 tentang Penataan Ruang dan Perda Kota Malang No.4 Th.2011 tentang RTRW Kota Malang Tahun 2010-2030 dengan menyelaraskan atau mengharmonisasikan ketentuan sanksi administratif dan atau perdata merujuk UU No.32 Th.2009.

\section{DAFTAR PUSTAKA}

\section{Buku}

Absori, Hukum Penyelesaian Sengketa Lingkungan Hidup, Surakarta, UMS Press,2009.

Adrian Sutedi, Hukum Perizinan Dalam sektor Pelayanan Publik, Jakarta, Sinar Grafika,2010

Amirudin, Zainal Asikin, Pengantar Metode Penelitian Hukum, Raja Grafindo Persada, Jakarta,2004.

A.Hamid S. Attamimi, Peranan Keputusan Presiden RI Dalam Penyelenggaraan Pemerintahan Negara, Jakarta, PPs. UI,1990.

Hakam Shah, Islam Agama Ramah lingkungan, Jakarta, Pustaka Al-Kautsar,2001

Baqir Manan, Ketentuan-ketentuan Tentang Pembentukan Perundang-Undangan Dalam Pembangunan Hukum Nasional, (Makalah disampaikan pada Pertemuan Ilmiah tentang kedudukan Biro-biro Hukum/Unit Kerja Departemen /LPND dalam Pembangunan Hukum, Jakarta,19-20 Oktober 1994).

Eko Budiardjo, Tata Ruang Perkotaan,Bandung, Alumni,1997.

Maria Farida Indrati S., Ilmu Perundang-undangan, Kanisius, Yogyakarta,2007. 
Philipus M. Hadjon, Pengkajian Ilmu Hukum, Pelatihan MetodePenelitian Hukum Normatif, Lemlit Unair bekerja sama dengan Fakultas Hukum Unair, 11- 12 Juni 1997.

Rachamadi Usman, Pembaharuan Hukum Lingkungan Nasional, Bandung, Citra Aditya Bakti,2003

Siti Sundari Rangkuti, Hukum Lingkungan Dan Kebijaksanaan Lingkungan Nasional, Surabaya Press, 1996.

\section{Peraturan Perundang-undangan}

UUD 1945 amandemen ke-IV

Undang-Undang RI Nomor 32 tahun 2009 tentang Perlindungan dan Pengelolaan Lingkungan Hidup

Undang-Undang RI Nomor 26 tahun 2007 tentang Penataan Ruang

Undang-undang RI Nomor 23 Tahun 2014 tentang Pemerintahan Daerah

Undang-Undang RI Nomor 12 Tahun $2011 \quad$ Tentang Pembentukan Peraturan Perundang-undangan

Undang-Undang RI Nomor2 Tahun 2015 tentang Penetapan Perpu Nomor 2 Tahun 2014 tentang Perubahan atas UU nomor 23 Tahun 2014 tentang Pemerintahan Daerah

Peraturan Daerah Kota Malang Nomor 4 Tahun 2011 tentang Rencana Tata Ruang Wilayah Kota Malang 2010-2030

\section{Internet}

http://www.setkab.go.id. 